\title{
Serum Carcinoembryonic Antigen Levels Before the First Curative Hepatectomy for Metastatic Colorectal Cancer Is a Predictor of Recurrence
}

\author{
HIDEJIRO KAWAHARA ${ }^{1}$, SEIYA YOSHIDA ${ }^{1}$, YOICHI TOHYAMA ${ }^{1}$, \\ SATORU YANAGISAWA ${ }^{1}$, TAKEYUKI MISAWA ${ }^{1}$ and KATSUHIKO YANAGA ${ }^{2}$ \\ ${ }^{1}$ Department of Surgery, Kashiwa Hospital, Jikei University School of Medicine, Chiba, Japan; \\ ${ }^{2}$ Department of Surgery, Jikei University School of Medicine, Tokyo, Japan
}

\begin{abstract}
Background/Aim: The aim of this study was to evaluate the usefulness of serum carcinoembryonic antigen (CEA) levels before the first curative hepatectomy for metastatic colorectal cancer as a predictor of recurrence. Patients and Methods: Between 2003 and 2010, 66 patients (45 male and 21 female) who underwent a first curative hepatectomy for metastatic colorectal cancer in our hospital were evaluated retrospectively. The mean patient age was 65.2 years (range $=31-80$ years). A total of 28 patients had synchronous liver metastasis, and the other 38 patients developed metachronous liver metastasis. Results: The 5-year relapse-free survival rate after the first hepatectomy of the 16 patients with normal serum CEA level was $61.1 \%$, whereas that of the 50 patients with abnormal serum CEA level was $34.3 \%(p<0.001)$. Among patients whose serum CEA levels were abnormal, the 5-year relapse-free survival rate after the first hepatectomy of the 34 patients with serum CEA levels less than $50 \mathrm{ng} / \mathrm{ml}$ was $48.1 \%$, whereas that of the 16 patients with serum CEA level equal to or greater than $50 \mathrm{ng} / \mathrm{ml}$ was $6.3 \%(p<0.001)$. All eleven patients whose serum CEA levels were at least $100 \mathrm{ng} / \mathrm{ml}$ developed recurrence within one year after hepatectomy. Conclusion: Serum CEA levels before the first curative hepatectomy for metastatic colorectal cancer seem to be a predictor of recurrence.
\end{abstract}

The liver is the most frequent recurrence site in patients with colorectal cancer $(1,2)$. A resection of liver metastasis is

Correspondence to: Hidejiro Kawahara, MD, Ph.D., Department of Surgery, Kashiwa Hospital, Jikei University School of Medicine, 163-1 Kashiwashita, Kashiwashi, Chiba 277-8567, Japan. Tel: +81 471641111 Ext. 3421, Fax: +81 471633488, e-mail: kawahide@jikei.ac.jp

Key Words: Carcinoembryonic antigen, metastatic colorectal cancer, hepatectomy. recommended in many situations, since it is currently the most effective therapy (3-5). However, $60 \%$ of patients experience tumor recurrence after the first liver resection (68 ), whereas only $20 \%$ to $30 \%$ of patients experienced curative treatment after the initial liver resection $(5,9,10)$. Carcinoembryonic antigen (CEA) is the most widely used tumor marker for patients with colorectal cancer. High preoperative serum CEA level indicates poor prognosis, and a postoperative increase or persistently high CEA level indicates disease recurrence. The aim of this study was to evaluate the usefulness of serum CEA level before the first curative hepatectomy for metastatic colorectal cancer as a predictor of recurrence.

\section{Patients and Methods}

Patients. Between 2003 and 2010, 66 patients (45 male and 21 female) underwent a first hepatectomy for metastatic colorectal cancer in our hospital and were evaluated by reviewing medical records. The mean patient age was 65.2 years (range $=31-80$ years). Twenty-eight of the patients $(42 \%)$ developed synchronous liver metastasis, and the other 38 patients $(58 \%)$ developed metachronous liver metastasis. Thirty of the patients $(45 \%)$ underwent partial liver resection, $20(31 \%)$ underwent segmentectomy, and the other 16 (24\%) underwent lobectomy. Serum CEA level before the first hepatectomy of 16 patients (24\%) was normal (Table I). No patients received chemotherapy after the first hepatectomy.

Our indication criteria for hepatectomy were according to the 2016 guidelines for the treatment of colorectal cancer (11), which consisted of the following five items. 1) The patient is capable of tolerating surgery, 2) the primary tumor has been controlled or can be controlled, 3) the metastatic liver tumor can be completely resected 4) there are no extrahepatic metastases, or they can be controlled, 5) The function of the remaining liver will be adequate.

Treatment schedule. Physical examinations, routine blood analyses, and serum CEA measurements were performed every two months after hepatectomy. Computed tomography (CT) was performed every six months or when a patient's serum CEA level was higher than the normal level of $5.0 \mathrm{ng} / \mathrm{ml}$. Positron emission tomography 
Table I. Clinicopathological features of the patients.

\begin{tabular}{ll}
\hline Characteristic & No. of patients \\
\hline Median age (range), years & $65.2(31-80)$ \\
Gender, n (\%) & \\
Male & $45(68)$ \\
Female & $21(32)$ \\
Primary site, n (\%) & \\
Colon & $49(74)$ \\
Rectum & $17(26)$ \\
Liver metastasis, n (\%) & \\
Synchronous metastases & $28(42)$ \\
Metachrous metastases & $38(58)$ \\
Surgical procedure, $\mathrm{n}(\%)$ & \\
Partial resection & $30(45)$ \\
Segmentectomy & $20(31)$ \\
Lobectomy & $16(24)$ \\
Number of metastatic lesions, $\mathrm{n}(\%)$ & \\
1 & $34(52)$ \\
$2-4$ & $20(30)$ \\
$5-$ & $12(18)$ \\
Serum CEA level, n (\%) & \\
Normal & $16(24)$ \\
$5<,<50$ & $34(51)$ \\
$50 \leq,<100$ & $5(8)$ \\
$100 \leq$ & $11(17)$ \\
\hline
\end{tabular}

(PET) or PET/CT was not routinely performed but was occasionally employed for patients who had equivocal conventional imaging studies to detect occult metastasis if indicated.

Statistical analysis. Continuous variables are expressed as the mean and range. The Wilcoxon rank-sum test was used for the comparison of continuous variables, and the chi-square test was used for the comparison of categorical data. Relapse-free survival rates after hepatectomy were examined by the Kaplan-Meier method and logrank test. A $p$-value of less than 0.05 indicated significance. All data were analyzed with SPSS version 24.0 (IBM Japan, Ltd, Tokyo, Japan).

\section{Results}

Comparison of patients with normal and abnormal serum CEA levels before the first curative hepatectomy. No significant differences were identified in age, gender, primary tumor site, type of liver metastasis, type of hepatectomy, or number of metastatic lesions (Table II).

Comparison of relapse-free survival rates after the first curative hepatectomy between patients with normal or abnormal serum CEA levels before hepatectomy. The 5-year relapse-free survival rate after hepatectomy for the 16 patients with normal serum CEA level was $61.1 \%$, whereas that of the 50 patients with abnormal serum CEA level was $34.3 \%$. A significant difference was found between the two groups $(p<0.001)$ (Figure 1).
Table II. Comparison between normal and abnormal in patients' serum CEA level before hepatectomy.

\begin{tabular}{|c|c|c|c|}
\hline Characteristic & $\begin{array}{c}\text { Normal } \\
(\mathrm{n}=16)\end{array}$ & $\begin{array}{c}\text { Abnormal } \\
(\mathrm{n}=50)\end{array}$ & $p$-Value \\
\hline Median age (range), years & $62.2(31-79)$ & $66.2(31-81)$ & 0.570 \\
\hline Gender, n (\%) & & & 0.070 \\
\hline Male & $8(50)$ & $37(74)$ & \\
\hline Female & $8(50)$ & $13(26)$ & \\
\hline Primary site, $\mathrm{n}(\%)$ & & & 0.743 \\
\hline Colon & $11(69)$ & $38(76)$ & \\
\hline Rectum & $5(31)$ & $12(24)$ & \\
\hline Liver metastasis, $\mathrm{n}(\%)$ & & & 0.250 \\
\hline Synchronous metastases & $9(56)$ & $19(38)$ & \\
\hline Metachrous metastases & $7(44)$ & $31(62)$ & \\
\hline Surgical procedure, n (\%) & & & 0.139 \\
\hline Partial resection & $8(50)$ & $21(42)$ & \\
\hline Segmentectomy & $7(44)$ & $14(28)$ & \\
\hline Lobectomy & $1(6)$ & $15(30)$ & \\
\hline \multicolumn{4}{|l|}{ Number of metastatic } \\
\hline lesions, n (\%) & & 0.283 & \\
\hline 1 & $11(69)$ & $23(46)$ & \\
\hline $2-4$ & $3(19)$ & $17(34)$ & \\
\hline $5-$ & $2(12)$ & $10(20)$ & \\
\hline
\end{tabular}

Comparison of patients with serum CEA levels of less than or at least $50 \mathrm{ng} / \mathrm{ml}$ before the first curative hepatectomy. In the 50 patients whose serum CEA level was abnormal, no significant differences were identified in age, gender, primary tumor site, type of liver metastasis, type of hepatectomy, or number of metastatic lesions (Table III).

Comparison of relapse-free survival rate after the first curative hepatectomy in patients with serum CEA levels less than or at least $50 \mathrm{ng} / \mathrm{ml}$ before hepatectomy. The 5-year relapse-free survival rate after hepatectomy of the 34 patients with serum CEA level less than $50 \mathrm{ng} / \mathrm{ml}$ was $48.1 \%$, whereas that of the 16 patients with serum CEA level at least $50 \mathrm{ng} / \mathrm{ml}$ was $6.3 \%$. A significant difference was found between the two groups $(p<0.001)$ (Figure 2).

Comparison of patients with a normal serum CEA level or a level of $100 \mathrm{ng} / \mathrm{ml}$ or higher before the first curative hepatectomy. There was a significant difference between the two groups in three factors: gender, number of metastatic lesions and recurrence within one year after the first curative hepatectomy. No significant differences were found in age, primary tumor site, type of liver metastasis, or type of hepatectomy. All eleven patients whose serum CEA levels were $100 \mathrm{ng} / \mathrm{ml}$ or higher experienced recurrence within one year after hepatectomy (Table IV). 


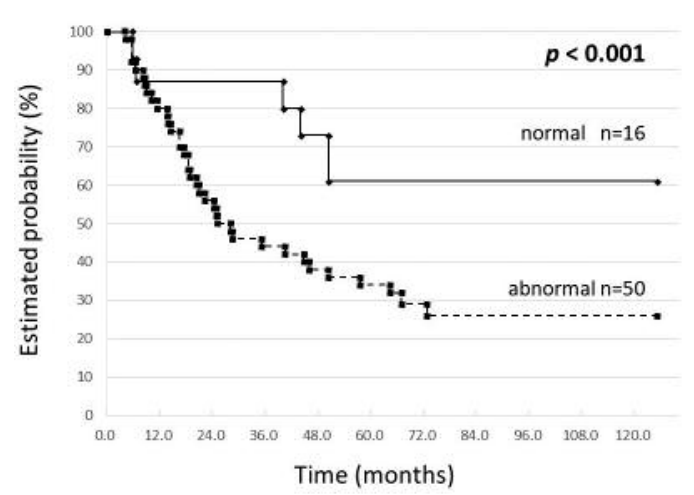

Figure 1. Comparison of relapse-free survival rates after the first curative hepatectomy between patients with normal and abnormal serum CEA level before the hepatectomy. A significant difference was identified between the two groups $(p<0.001)$.

Table III. Comparison of patients' serum CEA level before hepatectomy between less than $50 \mathrm{ng} / \mathrm{ml}$ and $50 \mathrm{ng} / \mathrm{ml}$ or more.

\begin{tabular}{lccc}
\hline Characteristic & $\begin{array}{c}\text { less than } \\
50 \mathrm{ng} / \mathrm{ml} \\
(\mathrm{n}=34)\end{array}$ & $\begin{array}{c}50 \mathrm{ng} / \mathrm{ml} \\
\text { or more } \\
(\mathrm{n}=16)\end{array}$ & $p$-Value \\
& $66.7(31-79)$ & $65.2(31-80)$ & 0.574 \\
\hline $\begin{array}{l}\text { Median age (range), years } \\
\text { Gender, n (\%) }\end{array}$ & $24(50)$ & $13(81)$ & 0.508 \\
$\quad$ Male & $10(50)$ & $3(19)$ & \\
Female & & & 1.000 \\
Primary site, n (\%) & $26(69)$ & $12(75)$ & \\
Colon & $8(31)$ & $4(25)$ & 1.000 \\
Rectum & & & \\
Liver metastasis, $\mathrm{n}(\%)$ & $6(38)$ & \\
$\quad$ Synchronous metastases & $13(56)$ & $10(62)$ & \\
$\quad$ Metachrous metastases & $21(44)$ & & \\
Surgical procedure, $\mathrm{n}(\%)$ & & $5(31)$ & \\
Partial resection & $16(50)$ & $5(31)$ & \\
Segmentectomy & $9(44)$ & $6(38)$ & \\
Lobectomy & $9(6)$ & 0.261 & \\
Number of metastatic & & $5(31)$ & \\
lesions, n (\%) & & $6(38)$ & \\
1 & $18(69)$ & $5(31)$ & \\
2-4 & $11(19)$ & $5(12)$ & \\
5- & &
\end{tabular}

\section{Discussion}

Colorectal cancer recurrence after liver resection for metastasis remains a great concern, and the reported recurrence rates are up to $60 \%$ (6-8). Serum CEA level is the most widely used tumor marker for patients with colorectal cancer. Accordingly, the usefulness of serum CEA level

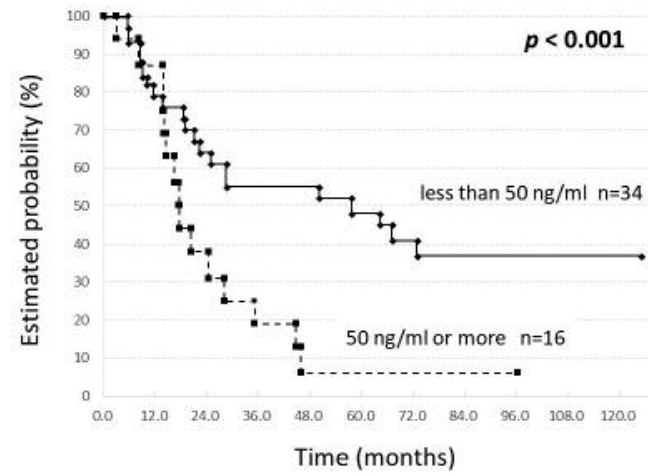

Figure 2. Comparison of relapse-free survival rates after the first curative hepatectomy between patients with serum CEA level of less than $50 \mathrm{ng} / \mathrm{ml}$ and equal or more than $50 \mathrm{ng} / \mathrm{ml}$ before the hepatectomy. A significant difference was identified between the two groups $(p<0.001)$.

Table IV. Comparison of patients' serum CEA level before hepatectomy between normal and $100 \mathrm{ng} / \mathrm{ml}$ or more.

\begin{tabular}{|c|c|c|c|}
\hline Characteristic & $\begin{array}{c}\text { Normal } \\
(\mathrm{n}=16)\end{array}$ & $\begin{array}{c}100 \mathrm{ng} / \mathrm{ml} \\
\text { or more }(\mathrm{n}=11)\end{array}$ & $p$-Value \\
\hline Median age (range), years & $62.2(31-79)$ & $64.5(31-80)$ & 0.868 \\
\hline Gender, n (\%) & & & 0.042 \\
\hline Male & $8(50)$ & $10(91)$ & \\
\hline Female & $8(50)$ & $1(9)$ & \\
\hline Primary site, n (\%) & & & 1.000 \\
\hline Colon & $11(69)$ & $8(73)$ & \\
\hline Rectum & $5(31)$ & $3(27)$ & \\
\hline Liver metastasis, n (\%) & & & 0.440 \\
\hline Synchronous metastases & $9(56)$ & $4(36)$ & \\
\hline Metachrous metastases & $7(44)$ & $7(64)$ & \\
\hline Surgical procedure, $\mathrm{n}(\%)$ & & & 0.284 \\
\hline Partial resection & $8(50)$ & $3(27)$ & \\
\hline Segmentectomy & $7(44)$ & $8(73)$ & \\
\hline Lobectomy & $1(6)$ & $0(0)$ & \\
\hline \multicolumn{4}{|l|}{ Number of metastatic } \\
\hline lesions, $\mathrm{n}(\%)$ & & & 0.034 \\
\hline 1 & $11(69)$ & $2(18)$ & \\
\hline $2-4$ & $3(19)$ & $6(55)$ & \\
\hline $5-$ & $2(12)$ & $3(27)$ & \\
\hline $\begin{array}{l}\text { Recurrence within one year } \\
\text { after hepatectomy, } \mathrm{n}(\%)\end{array}$ & & & $<0.001$ \\
\hline Presence & $1(6)$ & $11(100)$ & \\
\hline Absence & $15(94)$ & $0(0)$ & \\
\hline
\end{tabular}

before the first curative hepatectomy for metastatic colorectal cancer as a predictor of recurrence was evaluated. Circulating tumor cells (CTCs) are also considered a prognostic factor (12-14); however, determining CTC levels is not currently common due to its high cost and complicated 
protocol. A correlation between serum CEA and CTC levels was reported: CTCs appear when serum CEA is at least 10fold higher than normal $(50 \mathrm{ng} / \mathrm{ml})$, and any subsequent increase in serum CEA level is associated with an increase in CTCs $(15,16)$. Therefore, the CEA cut-off levels in this study were 5 and $50 \mathrm{ng} / \mathrm{ml}$.

When patients with normal and abnormal serum CEA levels before the first curative hepatectomy were compared, no significant differences were identified in their background. However, a significant difference in the 5-year relapse-free survival rate after hepatectomy was found between the two groups When the 50 patients with abnormal serum CEA levels of $50 \mathrm{ng} / \mathrm{ml}$ or less before the first curative hepatectomy were compared no significant differences were identified in their background. However, a significant difference was found between the two groups in the 5-year relapse-free survival rate after hepatectomy. Since CTCs appear in patients with a serum CEA level of $50 \mathrm{ng} / \mathrm{ml}$ or higher, which represents a 10-fold increase above normal (15), CTCs seem to contribute to recurrence. These patients may receive chemotherapy, such as an infusion of fluorouracil and leucovorin combined with either oxaliplatin (FOLFOX) or irinotecan (FOLFIRI), to kill CTCs before hepatectomy. However, in cases of resectable liver metastasis, the administration of chemotherapy before liver resection remains arguable. During the period of chemotherapy, tumor progression could occur, possibly leading to an unresectable status if the metastatic lesion is not susceptible to chemotherapy (17-19).

Mitsuyama et al. (20) reported that patients whose serum CEA level was $100 \mathrm{ng} / \mathrm{ml}$ or higher before chemotherapy and who had unresectable liver metastasis had a poor prognosis. In this study, all eleven patients whose serum CEA level was $100 \mathrm{ng} / \mathrm{ml}$ or higher experienced recurrence within one year after the first curative hepatectomy. These patients may be at high risk for hepatic metastasis if curative hepatectomy is possible. The indication of hepatectomy for these patients should be considered very carefully.

In conclusion, serum CEA levels before the first curative hepatectomy for metastatic colorectal cancer seem to be a predictor of recurrence; however, a large-scale prospective study is needed to clarify this issue.

\section{Conflicts of Interest}

The Authors declare that there are no conflicts of interest regarding this study.

\section{References}

1 Manfredi S, Lepage C, Hatem C, Coatmeur O, Faivre J and Bouvier AM: Epidemiology and management of liver metastases from colorectal cancer. Ann Surg 244: 254-259, 2006.

2 Tomlinson JS, Jarnagin WR, DeMatteo RP, Fong Y, Kornprat P, Gonen M, Kemeny N, Brennan MF, Blumgart LH and
D'Angelica M: Actual 10-year survival after resection of colorectal liver metastases defines cure. J Clin Oncol 25: 45754580, 2007.

3 Choti MA, Sitzmann JV, Tiburi MF, Sumetchotimetha W, Rangsin R, Schulick RD,Lillemae KD, Yeo CJ and Cameron JL: Trends in long-term survival following liver resection for colorectal hepatic metastasis. Ann Surg 235: 759-766, 2002.

4 Fong Y, Fortner J, Sun RL, Brennan MF and Blumgart LH: Clinical score for predicting recurrence after hepatic resection for metastatic colorectal cancer: analysis of 1001 consecutive cases. Ann Surg 230: 309-318, 1999.

5 Pawlik TM, Schlick RD and Choti MA: Expanding criteria for resectability of colorectal liver metastases. Oncologist 13: 5164, 2008.

6 Malafosse R, Penna C, Sa Cunha A and Nordlinger B: Surgical management of hepatic metastases from colorectal malignancies. Ann Oncol 12: 887-894, 2001.

7 Assumpcao L, Choti MA, Gleisner AL, Schulick RD, Swartz M, Herman J, Gearhart SL and Pawlik TM: Patterns of recurrence following liver resection for colorectal metastases: effect of primary rectal tumor site. Arch Surg 143: 743-749, 2008.

8 Frankel TL and D'Angelica MI: Hepatic resection for colorectal metastases. J Surg Oncol 109: 2-7, 2014.

9 Suzuki S, Sakaguchi T, Yokoi Y, Kurachi K, Okamoto K, Okumura T, Tsuchiya Y, Nakamura T, Konno H, Baba S and Nakamura S: Impact of repeat hepatectomy on recurrent colorectal liver metastases. Surgery 129: 421-428, 2001.

10 Yokoi Y, Suzuki S and Nakamura S: The impact of hepatic resection on metastatic colorectal cancer. Jpn J Cancer Chemother 29: 848-855, 2002.

11 Watanabe T, Muro K, Ajioka Y, Hashiguchi Y, Ito Y, Saito Y, Hamaguchi T, Ishida H, Ishiguro M, Ishihara S, Kanemitsu Y, Kawano H, Kinugasa Y, Kokudo N, Murofushi K, Nakajima T, Oka S, Sakai Y, Tsuji A, Uehara K, Ueno H, Yamazaki K, Yoshida M, Yoshino T, Boku N, Fujimori T, Itabashi M, Koinuma N, Morita T, Nishimura G, Sakata Y, Shimada Y, Takahashi K, Tanaka S, Tsuruta O, Yamaguchi T, Yamaguchi N, Tanaka T, Kotake K and Sugihara K; Japanese Society for Cancer of the Colon and Rectum: Japanese Society for Cancer of the Colon and Rectum (JSCCR) guidelines 2016 for the treatment of colorectal cancer. Int J Clin Oncol 23: 1-34, 2018.

12 Cohen SJ, Punt CJ, Iannotti N, Saidman BH, Sabbath KD, Gabrail NY, Picus J, Morse M, Mitchell E, Miller MC, Doyle GV, Tissing H, Terstappen LW and Meropol NJ: Relationship of circulating tumor cells to tumor response, progression-free survival and overall survival in patients with metastatic colorectal cancer. J Clin Oncol 26: 3213-3221, 2008.

13 Cohen SJ, Punt CJ, Iannotti N, Saidman BH, Sabbath KD, Gabrail NY, Picus J, Morse MA, Mitchell E, Miller MC, Doyle GV, Tissing H, Terstappen LW and Meropol NJ: Prognostic significance of circulating tumor cells in patients with metastatic colorectal cancer. Ann Oncol 20: 1223-1229, 2009.

14 Yalcin S, Kilickap S, Portakal O, Arslan C, Hascelik G and Kutluk T: Determination of circulating tumor cells for detection of colorectal cancer progression or recurrence. HepatoGastroenterol 57: 1395-1398, 2010.

15 Kawahara H, Watanabe K, Toyama Y, Yanagisawa S, Kobayashi $\mathrm{S}$ and Yanaga K: Determination of circulating tumor cells for prediction of recurrent colorectal cancer progression. HepatoGastroenterol 59: 2115-2118, 2012. 
16 Neki K, Kawahara H, Watanabe K, Toyama Y, Akiba T and Yanaga K: Usefulness of circulating tumor cells after preliminary chemotherapy prediction of response to further anticancer therapy in patients with initially unresectable metastatic colorectal cancer. Anticancer Res 33: 1769-1772, 2013.

17 Lehmann K, Rickenbacher A, Weber A, Pestalozzi BC, and Clavien PA: Chemotherapy before liver resection of colorectal metastases: friend or foe? Ann Surg 255: 237-247, 2012.

18 Nanji S, Cleary S, Ryan P, Guindi M, Selvarajah S, Al-Ali H, Grieg P, McGilvary I, Taylor B, Wei A, Moulton CA and Gallinger S: Up-front hepatic resection for metastatic colorectal cancer results in favorable long-term survival. Ann Surg Oncol 20: 295-304, 2013.
19 Ueno S, Sakoda M, Kitazono M, Iino S, Kurahara H, Minami K, Ando K, Mataki Y, Maemura K, Ishigami S and Natsugoe S: Is delayed liver resection appropriate for patients with metachronous colorectal metastases? Ann Surg Oncol 18: 1104-1109, 2011.

20 Mitsuyama Y, Shiba H, Haruki K, Fujiwara Y, Furukawa K, Iida T, Hayashi T, Ogawa M, Ishida Y, Misawa T, Kashiwagi H and Yanaga K: Carcinoembryonic antigen and carbohydrate antigen 19-9 are prognostic predictors of colorectal cancer with unresectable liver metastasis. Oncol Lett 3: 767-771, 2012.

Received August 6, 2018

Revised August 16, 2018

Accepted August 19, 2018 